\title{
TINJAUAN HUKUM PELAKSANAKAN PILKADES DESA SIDOMUKTI KECAMATAN ADIMULYO KABUPATEN KEBUMEN JAWA TENGAH
}

\author{
Oleh \\ Hasan Hamid Safri*)
}

hhsafri@unis.ac.id

\section{Abstrak}

Keberadaan pemerintah Desa diatur dalam perundang-undangan Negara Republik Indonesia melalui Undang-Undang No. 19 Tahun 1965 Tentang Desapraja, Undang-Undang Nomor 5 Tahun 1974 Tentang Pokok-Pokok Pemerintahan di Daerah, Undang-undang No. 5 Tahun 1979 Tentang Pemerintahan Desa. Undang-Undang Nomor 22 Tahun 1999 Tentang Pemerintahan Daerah (tidak berlaku lagi karena tidak sesuai dengan perkembangan keadaan, ketatanegaraan, dan tuntutan penyelenggaraan otonomi daerah sehingga perlu diganti). Undang-Undang Nomor 22 Tahun 1999 Tentang Pemerintahan Daerah (tidak berlaku lagi karena tidak sesuai dengan perkembangan keadaan, ketatanegaraan, dan tuntutan penyelenggaraan otonomi daerah sehingga perlu diganti). Undang-Undang Nomor 32 Tahun 2004 Tentang Pemerintahan Daerah, dalam pasal 239 menyatakan "Pada saat berlakunya Undang-Undang Ini, maka Undang-Undang Nomor 22 Tahun 1999 tentang pemerintahan daerah dinyatakan tidak berlaku. Perubahan Atas UU No. 32 Tahun 2004 Tentang Pemerintahan Daerah (Peraturan Pemerintahan Pengganti Undang-Undang RI Nomor 3 Tahun 2005) Perubahan Kedua Atas UU No. 32 Tahun 2004 Tentang Pemerintahan Daerah (UU No. 12 Tahun 2008). Undang-Undang Nomor 23 Tahun 2014 Tentang Pemerintahan Daerah menyatakan mencabut dan dinyatakan tidak berlaku : pertamaUU No. 5 Tahun 1962 Tentang Perusahaan Daerah, kedua UU No. 32 Tahun 2004 Tentang Pemerintah Daerah, sebagaimana telah diubah beberapa kali terakhir dengan UU No. 12 Tahun 2008 Tentang Perubahan Kedua Atas UU No. 32 Tahun 2004 Tentang Pemerintahan Daerah UU No. 28 Tahun 2009 Tentang Pajak Daerah dan Restribusi Daerah. Undang-Undang Nomor 6 Tahun 2014 Tentang Desa, didalam pasal 121 menyatakan : pada saat UU ini berlaku Pasal 200 pasal 2016 UU No. 32 Tahun 2004 Tentang Pemda, sebagaimana telah diubah beberapa kali terakhir dengan UU No. 12 Tahun 2008 Tentang Perubahan kedua UU No 32 Tahun 2004 Tentang Pemerintahan Daerah dicabut dan dinyatakan tidak berlaku. Desa adalah desa dan desa adat atau yang disebut dengan nama lain, selanjutnya disebut desa, adalah kesatuan masyarakat hukum yang memiliki batas wilayah yang berwenang untuk mengatur dan mengurus urusan pemerintahan, kepentingan masyarakat setempat beradsarkan prakarsa masyarakat, hak asal usul, danatau hak tradisional yang diakui dan dihormati dalam sistem pemerintahan Negara Kesatuan Republik Indonesia Pemilihan kepala desa Sidomukti adalah untuk melaksanakan amanah dari perundang-undangan yang berlau, sehingga tujuan dari penyelenggaraan pemerintahan yang paling bawah ini dapat terlasana dengan baik dan damai. Hasil pilkades Sidomukti saudara Suparmin (petahana) memperoleh 501 (lima ratus satu) suara, saudara Bayu Ikhtiar memperoleh 19 (sembilan belas) suara, saudara Heru Hudiyono memperoleh 622 (enam ratus dua puluh dua) suara, dan saudara Jono Riyanto memperoleh 430 (empat ratus tiga puluh) suara.

\section{Kata Kunci : Pemilihan Kepada Desa Sidomukti}

*) Penulis adalah Dosen Fakultas Hukum Universitas Islam Syekh Yusuf 


\section{A.PENDAHULUAN}

Sejarah pemerintah daerah dari sejak orde lama Ir Soekarno dan pemerintahan orde baru presiden H.M Soeharto smapai era reformasi sekarang ini, mulai diatur melalui peraturan perundang-undangan dalam sebutan Desapraja, melalui Undang-Undang No. 19 Tahun 1965 Tentang Desapraja. Desa atau nama lain telah ada sebelum Negara Kesatuan Republik Indonesia berdiri. Undang-Undang Dasar Indonesia Tahun 1945 (sebelum perubahan) menyebutkan bahwa dalam teori Negara Indonesia terdapat lebuh kurang 250 "Zel Iandschappen" dan Volkogemeeschappen" seperti desa di Jawa dan Bali, Nagari di Minangkabau, dusun dan marga di Palembang dan sebagainya. Negara Republik Indonesia menghormati kedudukan daerah-daerah itu dan segala peraturan Negara yang mengenai daerahdaerah itu akan adanya hak-hak asal usul daerah tersebut, oleh sebab itu, keberadaannya wajib tetap diakui dan diberikan jaminan keberlangsungan Negara Kesatuan Republik Indonesia.

Beberapa peraturan perundangundangan yang mengatur tentang Pemerintah Daerah yaitu :

1. Undang-Undang Nomor 19 Tahun 1965 Tentang Desapraja (Lembaran Negara Tahun 1965 Nomor 84)

2. Undang-Undang Nomor 5 Tahun 1974 Tentang Pokok-Pokok Pemerintahan di Daerah (Lembaran Negara Tahun Nomor 38, Tambahan Lembaran Negara 3037)

3. Undang-Undang Nomor 5 Tahun 1979 Tentang Pemerintahan Desa (Lembaran Negara Tahun 1979 Nomor 56 Tambahan Lembaran Negara Nomor 3153)

4. Undang-Undang Nomor 22 Tahun 1999 Tentang Pemerintahan Daerah (tidak berlaku lagi karena tidak sesuai dengan perkembangan keadaan, ketatanegaraan, dan tuntutan penyelenggaraan otonomi daerah sehingga perlu diganti).

5. Undang-Undang Nomor 32 Tahun 2004 Tentang Pemerintahan Daerah, dalam pasal 239 menyatakan "Pada saat berlakunya Undang-Undang Ini, maka Undang-Undang Nomor 22 Tahun 1999 tentang pemerintahan daerah dinyatakan tidak berlaku.

6. Perubahan Atas UU No. 32 Tahun 2004 Tentang Pemerintahan Daerah (Peraturan Pemerintahan Pengganti Undang-Undang RI Nomor 3 Tahun 2005) yang merubah pasal 90 dan diantara pasal 236 disisipkan 2 pasal baru yaitu pasal 236A dan pasal 236B

7. Perubahan Kedua Atas UU No. 32 Tahun 2004 Tentang Pemerintahan Daerah (UU No. 12 Tahun 2008) yang merubah pasal : 26, 42, 56, 58, 59, 59A, 60, 62, 63, 64, 75, 107 ayat (2) dan ayat (4), 108, 115 titambah 3 ayat yaitu ayat (7), (8), dan (9), 233 ayat (1) dihapus, ayat (2) diubah, dan ditambah 1 ayat yaitu ayat (3), 235, diubah dan ditambah 1 ayat, 237 diantara pasal 236 dan pasan 237 disisipkan 3 pasal yaitu pasal 236A, 236B, dan 236C, diantara pasal 239 dan pasal 240 disisipkan 1 pasal yaitu pasal 239A

8. Peraturan Menteri Dalan Negeri No. 23 Taun 2010 Tentang Tata Cara Pelaksanaan Evaluasi Perkembangan Daerah Otonomi Baru

9. Peraturan Menteri Dalam Negeri No. 53 Tahun 2010 Tentang Perubahan Atas Peraturan Mentei Dalam Negeri No. 31 Tahun 2005 Tentang Petunjuk Teknis Pelaksanaan Tugas Dewan Pertimbangan Otonomi Daerah.

10. Undang-Undang Nomor 23 Tahun 2014 Tentang Pemerintahan Daerah yang berisi 411 pasal dibuat pada 
akhir pemerintahan era presiden Dr. H. Susilo Bambang Yudhoyono yang disahkan pada tanggal 30 September 2014 dalam pasal 409 menyatakan mencabut dan dinyatakan tidak berlaku :

a. UU No. 5 Tahun 1962 Tentang Perusahaan Daerah (LN RI Tahun 1962 No. 10, TLN RI No. 2387)

b. UU No. 32 Tahun 2004 Tentang Pemerintah Daerah (LN Tahun 2004 No. 125, TLN RI No. 4437) sebagaimana telah diubah beberapa kali terakhir dengan UU No. 12 Tahun 2008 Tentang Perubahan Kedua Atas UU No. 32 Tahun 2004 Tentang Pemerintahan Daerah (LN RI Tahun 2008 No. 59, TLN RI No. 4844)

c. Pasal 157, pasal 158 ayat (2) sampai dengan ayat (9), dan pasal 159 UU No. 28 Tahun 2009 Tentang Pajak Daerah dan Restribusi Daerah (LN RI Tahun 2009 No. 130, TLN RI No. 5049), dan

d. Pasal 1 angka 4, pasal 314 sampai dengan pasal 412, pasal 418 sampai dengan pasal 421 UU No. 12 Tahun 2014 Tentang MPR, DPR, DPD, dan DPRD (LN RI Tahun 2014 No. 183, TLN No. 5568)

e. Undang-Undang Nomor 6 Tahun 2014 Tentang Desa, didalam pasal 121 menyatakan : pada saat UU ini berlaku Pasal 200 - pasal 2016 UU No. 32 Tahun 2004 Tentang Pemda (LN RI Tahun 2004 No. 125, TLN RI No. 4437) sebagaimana telah diubah beberapa kali terakhir dengan UU No. 12 Tahun 2008 Tentang Perubahan kedua UU No 32 Tahun 2004 Tentang Pemerintahan Daerah (LN Tahun 2008 No. 59, TLN RI No. 4844) dicabut dan dinyatakan tidak berlaku.

f. Peraturan Pemerintah RI Nomor 43 Tahun 2014 Tentang Peraturan
Pelaksanaan UU No. 6 Tahun 2014 Tentang Desa.

Definisi Desa adalah Desa dan Desa adat atau yang disebut dengan nama lain, selanjutnya disebut Desa adalah kesatuan masyarakat hukum yang memiliki batas wilayah yang berwenang untuk mengatur dan mengurus urusan pemerintahan, dan kepentingan masyarakat setempat berdasarkan prakarsa masyarakat, hak asal usul, dan atau hak tradisional yang diakui dan dihormati dalam system pemerintahan Negara Kesatuan Republik Idonesia (pasal 1 ayat (1) UU No. 6 Tahun 2014 Tentang Desa). Pemerintah desa dipimpin oleh seorang kepala desa atau yang disebut dengan nama lain, dibantu oleh perangkat desa sebagai unsur penyelenggaraan pemerintah desa.

Setiap Pemerintahan desa juga terdapat Badan Permusyawaratan Desa (BPD) atau yang disebut dengan nama lain adalah lembaga yang melaksanakan fungsi pemerintahan yang anggotanya merupakan dari penduduk Desa berdasarkan keterwakilan wilayah dan ditetapkn secara demokratis.

Musyawarah Desa atau disebut dengan nama lain adalah musyawarah antar Badan Permusyawaratan Desa, Pemerintah desa, dan unsur masyarakat yang diselenggarakan oleh Badan Permusyawaratan Desa menyepakati hal yang bersifat strategis.

Pemerintahan desa dapat memiliki Badan Usaha Milik Desa (B.U.M.Desa) adalah badan usaha yang seluruh atau sebagian besar modalnya dimiliki oleh desa melalui penyertaan secara langsung yang berasal dari kekayaan Desa yang dipisahkan guna mengelola asset, jasa pelayanan, dan usaha lainnya unruk sebesar-basarnya kesejahteraan masyarakat Desa.

Pemerintahan desa dapat membuat Peraturan Desa yaitu peraturan perundang-undangan yang ditetapkan 
olek Kepala Desa setelah dibahas dan disepakati berdasarkan Badan Permusyawaratan Desa (BPD).

Pemerintahan Desa dalam melaksanakan pembangunan masyarakat desanya dengan tujuan meningkatkan kualitas hidup dan kehidupan untuk sebesarbesarna untuk kesejahteraan masyarakat Desa. Pemberdaayaan masyarakat Desa adalah upaya mengembangkan kemandirian dan kesejahteraan masyarakat dengan meningkatkan pengetahuan, sikap, ketrampilan, perilaku, kemampuan, kesadaran, serta memanfaatkan sumber daya melalui penetapan kebijakan, program, kegiatan, dan pendampingan yang sesuai dengan esensi masalah dan prioritas kebutuhan masyarakat Desa.

Keuangan pemerintahan Desa meliputi semua hak dan kewajiban Desa yang dapat dinilai dengan uang serta segala sesuatu berupa uang dan barang yang berhubungan dengan pelaksanaan hak dan kewajiban Desa. Asset (kekayaan) pemerintahan Desa adalah barang milik desa yang berasal dari kekayaan asli Desa, dibeli atau diperoleh atas beban Anggaran Pendapatan dan Belanja Desa atau perolehan hak lainnya yang sah.

Pemerintah, pemda Propinsi, dan pemda Kabupaten/Kota dapat melakukan penataan : pembentukan, penghapusan, penggabungan, perubahan status, dan penetapan Desa. Desa terdiri dari desa dan desa adat disesuaikan dengan penyebutan yang berlaku di daerah setempat, pembentukan desa ditetapkan dengan peraturan daerah (Perda) Kabupaten/Kota dengan mempertimbangkan prakarsa masyarakat desa, asal usul, adat istiadat, kondisi sosial budaya masyarakat desa, serta kemampuan dan potensi Desa.

Kewenangan Pemerintah Desa meliputi ;

1. Kewenangan berdasarkan asal usul

2. Kewenangan lokal bersekala desa
3. Kewenangan yang ditugaskan oleh pemerintah, pemda Propinsi, atau pemda Kabupaten/Kota

4. Kewenangan lain yang ditugaskan oleh pemerintah, pemda Propinsi, atau pemda Kabupaten/Kota sesuai dengan ketentuan peraturan perundang-undangan.

Penyelenggaraan Pemerintah Desa Berdasarkan Azas :

1. Kepastian hukum

2. Tertib penyelenggaraan pemerintahan

3. Tertib kepentingan umum

4. Keterbukaan

5. Proporsionalitas

6. Profesionalitas

7. Akuntabilitas

8. Efektifitas dan efisiensi

9. Kearifan local

10. Keberagaman, dan

11. Partisipatif

Tugas Kepala Desa meliputi :

1. Menyelenggarakan pemerintah Desa

2. Melaksanakan pembangunan Desa

3. Pembinaan kemasyarakatan Desa, dan

4. Pemberdayaan masyarakat Desa

Wewenang Kepala Desa meliputi :

1. Memimpin penyelenggaraan pemerintahan Desa

2. Mengangkat dan memberhentikan perangkat Desa

3. Memegang kekuasaan pengelolaan euangan dan aset Desa

4. Menetapkan peraturan Desa

5. Menetapkan Anggaran Pendapatan dan Belannja Desa (APBDes)

6. Membina kehidupan masyarakat Desa

7. Membina ketentraman dan ketertiban masyarakat Desa

8. Membina dan meningkatkan perekonomian desa serta menginterasikannya agar mencapai perekonomian skala produktif untuk sebesarbesarnya kemakmuran masyarakat Desa 
9. Mengembangkan sumber pendapatan Desa

10. Mengusulkan dan menerima pelimpahan sebagian kekayaan Negara guna meningkatkan kesejahteraan masyarakat Desa

11. Mengembangkan kehidupan sosial budaya masyarakat Desa

12. Memanfaatkan teknologi tepat guna

13. Mengordinasikan pembangunan desa secara partisipatif

14. Mewakili desa di dalam dan di luar pengadilan atau menunjuk kuasa hukum untuk mewakilinya sesuai dengan ketentuan perundangundangan, dan

15. Melaksanakan wewenang lain yang sesuai dengan ketentuan perundangundangan.

Kepala Desa berhak ;

1. Mengusulkan struktur oeganisasi dan tata kerja pemerintahan Desa

2. Mengajukan rancangan dan menetapkan Peraturan Desa (Perdes)

3. Menerima penghasilan tetap setiap bulan, tunjangan, dan penerimaan lain yang sah, serta mendapat jaminan kesehatan

4. Mendapatkan perlindungan hukum atas kebijakan yang dilaksanakan, dan

5. Memberikan mandat pelaksanaan tugas dan kewajiban lainnya kepada perangkat Desa.

Kepala Desa memiliki kewajibankewajiban yaitu :

1. Memegang teguh dan mengamalkan Pancasila dan UUD 1945 serta mempertahankan dan memelihara keutuhan N.K.R.I dan Bhineka Tunggal Ika

2. Meningkatkan kesejahteraan masyarakat Desa

3. Memelihara ketentraman dan ketertiban masyarakat Desa

4. Menaati dan menegakan peraturan perundang-undangan

5. Melaksanakan kehidupan demokrasi berkeadilan gender
6. Melaksanakan prinsip tata pemerintahan desa yang akuntabel, transparan, professional, efektif dan efisien, serta bebas dari kolusi, korupsi, dan nepotisme.

7. Menjalin kerja sama dan koordinasi dengan seluruh pemangku kepentingan di Desa

8. Menyelenggarakan administrasi pemerintahan desa yang baik

9. Mengelola keuangan dan aset Desa

10. Melaksanakan urusan pemerintahan yang menjadi kewenangan Desa

11. Menyelesaikan perselisihan masyarakat di Desa

12. Mengembangkan perekonomian masyarakat Desa

13. Membina dan melestarikan nilai sosial budaya masyarakat Desa

14. Memberdayakan masyarakat dan lembaga kemasyarakatan di Desa

15. Mengembangkan potensi sumber daya alam dan melestarkan lingkungan hidup, dan

16. Memberikan informasi kepada masyarakat Desa

Kepala Desa dalam melaksanakan tugas, kewenangan, dan kewajiban, kepala Desa wajib :

1. Menyampaikan laporan penyelenggaraan Pemerintahan Desa setiap akhir tahun anggaran kepada Bupati/Walikota

2. Menyampaikan laporan penyelenggaraan Pemerintah Desa pada akhir masa jabatan kepada Bupati/ Walikota

3. Memberikan laporan keterangan penyelenggaraan pemeintahan secara tertulis kepada badan permusyawaratan desa (B.P.D) setiap akhir tahun anggaran, dan

4. Memberikan dan atau menyebarkan informasi penyelenggaraan pemerintahan secara tertulis kepada masyarakat desa setiap akhir tahun anggaran. 
Bagi kepala Desa yang tidak melaksanakan kewajiban tersebut dikenai sanksi administrasi berupa teguran lisan dan atau teguran tertulis, bila sanksi administrasi telah diberikan namun kepala Desa masih belum melaksanakan kewajibannya, maka dilakukan tindakan pemberhentian sementara dan dapat dilanjutkan dengan pemberhentian.

Larangan bagi Kepala Desa yaitu :

1. Merugikan kepentingan umum

2. Membuat keputusan yang menguntungkan diri sendiri, anggota keluarga, pihak lain, dan atau golongan tertentu

3. Menyalahgunakan wewenang, tugas, hak dan atau kewajibannya

4. Melakukan diskriminatif terhadap warga dan atau golongan masyarakat tertentu

5. Melakukan tindakan meresahkan kelompok masyarakat Desa

6. Melakukan korupsi, kolusi dan nepotisme (K.K.N), menerima uang, barang dan atau jasa dari pihak lain yang dapat mempengaruhi keputusannya atau tindakan yang akan dilakukannya

7. Menjadi pengurus partai politik

8. Menjadi anggota dan atau pengurus organisasi terlarang

9. Merangkap jabatan sebagai ketua dan atau anggola Badan Permusyawaratan Desa, anggota DPR RI, DPRD Propinsi atau DPRD Kabupaten/Kota, dan jabatan lain yang ditentukan dalam peraturan perundangundangan

10. Ikut serta dan atau terlibat dalam kampanye pemilihan umum dan atau pemelihan kepala daerah (Pilkada)

11. Melanggar sumpah/janji jabatan, dan

12. Meninggalkan tugas selama 30 (tiga puluh) hari kerja berturut-turut tanpa alasan yang jelas dan tidak dapat dipertanggungjawabkan.
Pemilihan kepala Desa dilaksanakan secara serentak di seluruh wilayah Kabupaten/Kota, maka pemerintah daerah Kabupaten/Kota menetapkan kebijakan pelaksanaan pemilihan kepala Desa secara serentak dengan Peraturan Daerah (Perda) kabupaten/ Kota. Ketentuan lebih lanjut mengenai tata cara pemilihan kepala Desa serentak diatur dengan atau berdasarkan Peraturan Pemerintah ( P.P ). Badan Permusyawaratan Desa memberitahukan kepada kepala Desa mengenai akan berakhirnya masa jabatan kepala Desa secara tertulis 6 (enam) bulan sebelum masa jabatannya berakhir dan membentuk panitia pemilihan Kepala Desa yang bersifat mandiri dan tidak memihak, panitia pemilihan terdiri atas unsur perangkat Desa, lembaga kemasyarakatan, dan tokoh masyarakat Desa.

Persyaratan Calon Kepala Desa yaitu :

1. Warga Negara Indonesia (W.N.I)

2. Bertakwa kepada Tuhan Yang Maha Esa

3. Memegang teguh dan mengamalkan Pancasila, melaksanakan UUD 1945 serta mempertahankan dan memelihara keutuhan N.K.R.I dan Bhineka Tunggal Ika

4. Berpendidikan paling rendah tamat sekolah menengah pertma atau sederajat

5. Berusia paling rendah 25 (dua puluh lima) tahun pada saat mendaftar

6. Bersedia dicalonkan menjadi kepala Desa

7. Terdaftar sebagai penduduk dan bertempat tinggal di desa setempat paling kurang 1 (satu) tahun sebelum pendaftaran

8. Tidak sedang menjalani hukuman pidana

9. Tidak pernah dijatuhi penjara pidana berdasarkan putusan pengadilan yang telah mempunyai kekuatan hukum tetap karena melakukan 
tindak pidana yang diancam dengan pidana penjara paling singkat 5 (lima) tahun atau lebih, kecuali 5 (lima) tahun setelah selesai menjalani pidana penjara dan mengumumkan secara jujur dan terbuka kepada publik bahwa yang bersangkutan pernah dipidana serta bukan sebagai pelaku kejahatan berulang-ulang

10. Tidak sedang dicabut hak pilihnya sesuai dengan putusan pengdilan yang telah mempunyai kekuatan hukum tetap

11. Berbadan sehat

12. Tidak pernah sebagai kepala Desa 3 (tiga) kali masa jabatan, dan

13. Syarat lain yang diatur dalam Peraturan Daerah

Mekanisme Pemilihan Kepala Desa:

1. Dipilih langsung oleh penduduk Desa

2. Pemilihan bersifat langsung, umum, bebas, rahasia, jujur, dan adil

3. Pemilihan dilaksanakan melalui tahap pencalonan, pemungutan suara, dan penetapan

4. Dibentuk panitia pemilihan kepala Desa

5. Panitia pemilihan kepala Desa berfungsi mengadakan penjaringan dan penyaringan bakal calon bedasarkan persyaratan yang ditentukan, melaksanakan pemungutan suara, menetapkan calon kepala Desa terpilih, dan melaporkan pelaksanaan pemilihan kepala desa

6. Biaya pemilihan kepala desa dibebankan pada Anggaran Pendapatan dan Belanja Daerah (APBD) Kabupaten/ Kota

7. Hak pilih diberikan kepada penduduk desa yang sudah berumur 17 (tujuh belas) tahun atau sudah pernah menikah

8. Calon kepala desa yang dinyatakan terpilih adalah calon yang memperoleh suara terbanyak

9. Panitia pemilihan kepala desa menetapkan calon kepala desa terpilih
10. Panitia pemilihan kepala desa terpilih menyerahkan kepada Badan Permusyawaratan Desa (BPD) paling lama 7 (tujuh) hari setelah penetapan calon kepala desa terpilih

11. Badan Permusyawaratan Desa paling lama 7 (tujuh) hari setelah menerima laporan panitia pemilihan menyampaikan nama calon Kepala Desa terpilih kepada Bupati/Walikota

12. Bupati/Walikota mengesahkan calon Kepala Desa terpilih menjadi Kepala Desa paling lama 30 (tiga puluh) hari sejak tanggal diterimanya penyampaian hasil pemilihan dari panitia pemilihan Kepala Desa dalam bentuk keputusan Bupati/Walikota

13. Dalam hal terjadi perselisihan hasil pemilihan Kepala Desa, Bupati/ Walikota wajib menyelesaikan perselisihan dalam jangka waktu 30 (tiga puluh) hari tersebut

14. Calon Kepala Desa terpilih dilantik oleh Bupati/Walikota atau pejabat yang ditunjuk paling lama 30 (tiga puluh) hari setelah penerbitan keputusan Bupati/Walikota

15. Sebelum memangku jabatannya, Kepala Desa terpilih bersumpah/ berjanji

16. Kepala Desa memegang jabatan selama 6 (enam) tahun terhitung sejak tanggal pelantikan

17. Kepala Desa dapat menjabat paling banyak 3 (tiga) kali masa jabatan secara berturut-turut atau tidak secara berturut-turut

Pemberhentian Kepala Desa :

1. Berakhir masa jabatannya

2. Tidak dapat melaksanakan tugas secara berkelanjutan atau berhalangan tetap secara berturut-turut selama 6 (enam) bulan

3. Tidak lagi memenuhi syarat sebagai Kepala Desa, atau

4. Melanggar larangan sebagai Kepala Desa 
Perangkat Desa terdri dari : Sekretaris Desa, pelaksanaan kewilayahan, dan pelaksana teknis. Perangkat Desa membantu Kepala Desa dalam melaksanakan tugas dan wewenangnya dan diangkat oleh Kepala Desa setelah dikonsultasikan dengan Camat atas nama Bupati/Walikota, perangkat Desa dalam melaksanakan tugas dan wewenangnya bertanggungjawab kepada Kepala Desa.

Perangkat Desa Dilarang :

1. Merugikan kepentingan umum

2. Membuat keputusan yang menguntungkan diri sendiri, anggota keluarga, pihak lain, dan atau golongan tertentu

3. Menyalahgunakan wewenang, tugas, hak, dan atau kewajibannya

4. Melakukan tindakan diskriminasi terhadap warga dan atau golongan masyarakat tertentu

5. Melakukan tindakan meresahkan sekolompok masyarakat Desa

6. Melakukan kolusi, korupsi, dan nepotisme (K.K.N), menerima uang, barang, dan atau jasa dari pihak lain yang dapat mempengaruhi keputusan atau tindakan yang akan dilakukannya

7. Menjadi pengurus partai politik

8. Menjadi anggota dan atau pengurus organisasi terlarang

9. Merangkap jabatan sebagai ketua dan atau anggota Badan Permusyawaratan Desa, anggota DPR RI, DPD RI, DPRD Propinsi, atau DPRD Kabupaten/Kota dan jabatan lain yang ditentukan dalam peraturan perundang-undangan

10. Ikut serta dan atau terlibat dalam kampanye pemilihan umum dan atau pemilihan kepala daerah

11. Melanggar sumpah/janji jabatan, atau

12. Meninggalkan tugas 40 (empat puluh) hari kerja berturut-turut tanpa alasan yang jelas dan tidak dapat dipertanggungjawabkan

Pengertian potensi Desa meliputi potensi fisik dan potensi nonfisi, potensi Desa merupakan segala sumber daya alam maupun sumber daya manusia yang terdapat, serta tersimpan di Desa. Semua sumber daya tersebut dapat dimanfaatkan bagi kelangsungan dan perkembangan Desa (Icuk Rangga Bawono dan Erwin Setyadi : 2019)

Dari uraian tersebut di atas, sebagai jawaban analisis hukum, maka timbul suatu pertanyaan, sebagai berikut :

1. Bagaimana mekanisme pemilihan kepala Desa?

2. Bagaimana hasil hasil dari pemilihan kepala Desa?

\section{B. PEMBAHASAN}

Pemerintah Daerah Kabupaten Kebumen melaksanakan Pemilihan Kepala Desa (Pilkades) serentak di 26 Kecamatan yang terbagi dalam 3 (tiga) gelombang : (http//dprd-kebumen.go.id diunduh Kamis, 20 Juni 2019 jam 20.33 WIB)

1. Gelombang I telah dilaksanakan pada tahun 2017

2. Gelombang II akan dilaksanakan pada tanggal 25 Juni 2019 di sejumlah 348 Desa yang rencana pelantikannya menyesuaikan dengan akhir masa jabatan masing-masing Kepala Desa tanggal 18 Juli 2019 sebanyak 115 Desa, 23 Juli 2019 sebanyak 101 Desa, 2 Agustus 2019 sebanyak 129 Desa, dan 16 September 20193 Desa.

3. Gelombang III direncanakan pelaksanaannya pada bulan Nopember 2019 sebanyak 52 Desa yang pelantikan Kepala Desa dilaksanakan pada bulan Desember 2019

Berdasarkan Perda Kabupaten Kebumen No. 10 Tahun 2016 Tentang Pemilihan, Pengangkatan, Pemberhentian 
Kepala Desa, Slogan Panitia Pilkades, pemilihan kepala Desa Sidomukti Tanggal 25 Juni 2019 dengan slogan sebagai berikut :

Mari kita wujudkan sebagai "PILKADES SERENTAK DI KABUPATEN KEBUMEN TAHUN 2019 YANG BERSIH DAN BERMARTABAT TANPA WUWURAN UNTUK MENCIPTAKAN APARATUR PEMERINTAH DESA YANG AMANAH, JUJUR, DAN DIPERCAYA MASYARAKAT “ Dilaksanakan pada hari Selasa, 25 Juni 2019

Pilkades 323 Desa di Kebumen Diikuti 949 Calon (www.kebumenekspres.com diunduh Kamis, 20 Juni 2019 Jam 20.55 wib).

Pelaksanaan pilkades tahap pertama Kabupaten Kebumen di tahun 2019 sebanyak 323 Desa telah menetapkan para calon kades yang bakal berkompetetisi pada tnggal 25 Juni 2019. Kepala Bidang Administrasi dan Kelembagaan Desa pada Dipermades Kebumen, Eko Purwanto, menetapkan calon dan Nomor urut sudah berlangsung dari tanggal 20-22 Mei 2019 hasilnya ada 323 Desa yang sudah menyelesaikan tahap penetapan calon Kades sekaligus pengundian Nomor urut, jumlah calon Kades yang telah ditetapkan dan mendapat nomor urut sebanyak 949 orang, kata Eko Purwanto Kamis (23/5/2019).

Dari 348 Desa yang direncanakan menggelar Pilkades pada 25 Juni 2019 sudah ada 323 Desa yang sudah siap menggelar Pilkades dan sisanya 25 Desa hingga 24 Mei 2019 dinyatakan belum siap karena adanya sejumlah persoalan di lapangan. Untuk yang 25 Desa ini masa pendaftarannya diperpanjang dan ada pula yang harus mengelola seleksi tambahan, kata Eko.

Bagi Desa yang sudah siap menggelar Pilkades, akan memasuki tahapan berikutnya, yakni Penandatanganan Pakta integritas secara serentak, tanggal 12 Juni 2019, Penyampaian undangan tanggal 10-18 Juni 2019, dan pelaksanaan Kampanye tanggal 19-21 Juni 2019 hari tenang 24 Juni 2019, pelaksanaan Pemungutan Suara tanggal 25 Juni 2019 yang serentak digelar di 52 Desa.

401 DESA DI KEBUMEN GELAR PILKADES SERENTAK www.kebumenekspres.com diunduh Kamis, 20 Juni 2019 jam 21.26.

Kabupaten Kebumen sedikitnya ada 4 agenda politik, baik tingkat nasional maupun dalam tataran daerah, yaitu pertama Pemilu Legislatif, kedua Pimilu Presiden dan Wakil Presiden (17 April 2019), ke tiga ada pengisian Wakil Bupati, dan ke empat Pilkades. Warga masyarakat dihimbau dapat bersama-sama menjaga kerukunan agar situasi Kamtibmas bisa terjaga. Dari ke empat gawe politik itu, hanya pemilihan wakil bupati saja yang tidak secara langsung melibatkan masyarakat karena tahapannya berada di DPRD Kebumen.

Sekda Kabupaten Kabumen, Ujang Sugiono menyatakan ada 401 Desa di Kebumen, Pilkades ini akan digelar 2 (dua) tahap yakni 348 Desa bakal menggelar Pilkades pada bulan Juni 2019 dan sisanya 53 Desa menggelar Pilkada pada Nopember 2019. Pilkades serentak, tak hanya karena masa jabatan yang sudah habis, sekaligus diharapkan dapat mengisi kekosongan jabatan Kades di sejumlah Desa di Kebumen. Total ada 18 Desa yang saat ini kosong alias tak memiliki Kades, dari jumlah itu, 14 diantaranya karena Kades memilih maju sebagai calon legislatif pada Pileg DPRD II di Kebumen. Sisanya 4 Desa karena tersandung persoalan korupsi dan diputus bersalah oleh majelis hakim. 
Profil Desa Sidomukti Kecamatan Adimulyo, Kabupaten Kebumen, Propinsi Jawa Tengah Tahun 2018 sebagai berikut :

Tahun

$: 2018$

Kode Desa (PUM)

: 3305152023

Desa/Kelurahan

: Sidomukti

: Adimulto

: Kebumen

Kabupaten/Kota

Propinsi

: Jawa Tengah

: 1925

Luas Wilayah Desa

: 274,057000

Hektar ( ha )

Dasar Hukum Perdes

Dasar Hukum Perda Kab

Peta Wilayah

Koordinat

/ 7,636841 LS

Tipologi

Klasifikasi

Kategori

Batas Wilayah

a. Desa Sebelah Utara

Sawangan

b. Desa Sebelah Selatan : Arjosari

c. Desa Sebelah Timur : Pekuwon

d. Desa Sebelah Sebelah Barat Jatimulyo

\section{A. PERSONIL}

1. Kepala Desa/Lurah

- Nama

: SUPARMIN

- Pangkat/Golongan

:-

- NIP

$:-$

- Pendidikan Terakhir : SLTP

- Pelatihan yang pernah diikuti :

a. Pelatihan Admininistrasi Pemerintahan Desa

b. Pelatihan Bumdes

c. Pelatihan Adminduk

- Jenis Kelamin : Laki-Laki

2. Sekretaris Desa/Kelurahan

- Nama : Hariyadi

- Pangkat/Golongan : -

- NIP :-

- Pendidikan Terakhir : SLTA

- Pelatihan yang pernah diikuti :

a. Pelatihan Penyusunan APBDes

b. Pelatihan Tanggap Bencana

c. Pelatihan Kearsipan

d. Pelatihan Pengelolaan Aset Desa

e. Pelatihan Produk Hukum Desa f. Pelatihan TKP2KDes

g. Pelatihan BPDT

h. Pelatihan Komputer

- Jenis Kelamin : Laki-Laki

3. Badan Permusyawaratan Desa (BPD)

- Nama (Ketua) : Suparman

- Pendidikan Terakhir : SLTA

- Pendidkan yang pernah diikuti :

a.Pelatihan BPD

b.Pelatihan Adminduk

c.Pelatihan Bumdes

d.Pelatihan Pembangunan Perpustakaan

\section{B. DATA UMUM}

1. Tataguna Lahan dan Produksi

a. Tataguna Lahan dan Produksi :

b. Sawah (Ha) : 179,4410

c. Tegal/ladang $(\mathrm{Ha})$ : 0,9710

d. Permukiman (Ha) : 8,7840

e. Pekaranganan (Ha) : 35,0640

f. Tanah Rawa (Ha) : 0,0000

g. Pasang Surut (Ha) : 0,0000

h. Lahan Gambut (Ha) : 0,0000

i. Situ/Waduk/Danau (Ha): 0,0000

j. Perkebunan (Ha) : 0,0000

k. Tanah Kas Desa (Ha) : $\mathbf{3 8 , 1 8 7 0}$

1. Fasilitas Umum (Ha) : 11,8900

m. Hutan (Ha) : 0,0000

n. Jumlah Luas Wilayah (Ha) : 274,3370

o. Produksi (Ha) : -

2. Rawan Bencana dan Orbitasi

a. Rawan Bencana

- Desa/Kelurahan Rawan Banjir (Ha) : -

- Desa/Kelurahan Potensial Tzunami (Ha) : -

- Desa/Kelurahan Rawan Jalur Gempa (Ha) :-

b. Orbitasi

- Jarak Ke Ibu Kota Kecamatan (Km)

: 5,000

- Waktu Tempuh dengan Kendaraan Bermotor : 0,75 jam

- Waktu Tempuh dengan Berjalan kaki/non motor : 1,50 jam

- Kendaraan umum ke Ibu Kota Kecamatan (Unit) : $\quad 0,00$

- Jarak ke Ibu Kota Kabupaten/Kota : $17,000 \mathrm{Km}$

- Waktu tempuh dengan Kendaraan Bermotor : 1,50 jam

- Waktu tempuh dengan Berjalan Kaki/non Bermotor : 2,50 jam 
- Kendaran Umum Ke Ibu Kota Kab/Kota (Init : 2

- Jarak Ke Ibu Kota Propinsi (Km) : 94,00

- Waktu tempuh dengan kendaraan bermotor : 5,00

- Waktu Tempuh dengan Berjalan Kaki/non motor : 14,00 Jam

- Kendaraan Umum Ke Ibu Kota Propinsi : 2 unit

3. Penduduk dan Kepala Keluarga

a. Jumlah Penduduk

- Jumlah Laki-Laki (orang) : 1.432

- Jumlah Perempuan (orang) : 1.521 Jumlah (orang) : 2.953

- Jumlah Kepala Keluaraga (KK): 1.017

- Kepadatan Pennduduk (Jiwa/Km²)

b. Komposisi Usia Penduduk : 107.773 Laki-Laki Perempuan

$\begin{array}{lrrr}\text { Usia 0-6 Tahun } & 118 & 127 & \\ \text { Usia 7-12 } & 118 & 116 & \\ \text { Usia 13-18 } & 129 & 108 & \\ \text { Usia 19-25 } & 169 & 148 & \\ \text { Usia 26-40 } & 320 & 319 & \\ \text { Usia 41-55 } & 264 & 309 & \\ \text { Usia 56-65 } & 159 & 174 & \\ \text { Usia 66-75 } & 159 & 118 & \\ \text { Usia > 75 } & 60 & 90 & \\ \text { Jumlah } & \mathbf{1 . 3 6 6} & \mathbf{1 . 4 1 9} & \\ \text { c. Kesejahteraan Keluarga } & & \\ \text { - Keluarga Prasejahtera (KK) } & : & 188 \\ \quad \text { - Keluarga Sejahtera 1 (KK) } & : & 175 \\ \quad \text { - Keluarga Sejahtera 2 (KK) } & : & 205 \\ \text { - Keluarga Sejahtera 3 (KK) } & : & 230 \\ \text { - Keluarga Sejahtera 3+ (KK) } & : & 245 \\ \text { Jumlah Kepala Keluarga } & : \mathbf{1 . 0 4 3}\end{array}$

4. Pekerjaan/Mata Pencaharian

Jenis Pekerjaan | Pria |Wanita |Jumlah

- Petani $237 \quad 239 \quad 476$

$\begin{array}{llll}\text { - Buruh Tani } & 72 & 42 & 114\end{array}$

$\begin{array}{llll}\text { - PNS } & 31 & 17 & 48\end{array}$

- Montir

$\begin{array}{lll}3 & 0 & 3\end{array}$

- Perawat Swasta 0066

- Bidan Swasta $0 \quad 2$

$\begin{array}{llll}\text { - POLRI } & 7 & 0 & 7\end{array}$

- Guru Swasta $\quad 17 \quad 38 \quad 55$

- Seniman/Artis $11 \quad 0 \quad 1$

- Pedgng kelling $\quad 0 \quad 11$

- Kry Pershn Swst $348184 \quad 532$
- Kry Prsh Pemrth

- Wiraswasta

- Tdk krj tetap

- Belum Bekeja

- Pelajar

- Ibu RT

5
70

0

26

5

- Purn/Pensiun

5
240

0

96

- Perangkat Desa

262

228

230

415

48

78

- Buruh Hrin Lps

11

23

- Tukang Jahit

- Tukang Rias

- Kary Honorer

- Tukang Cukur

Jumlah (Orang 1.461

$$
\begin{aligned}
& 3 \\
& 7
\end{aligned}
$$

7

0

3

2

0

468

492

415

125

14

30

7

3

3

3

2.950

5. Pendidikan dan Kesehatan

a. Rasio Murid dan Guru

Kategori Tingkat/Jenis Sekolah jml Pengajar jml Siswa Rasio

Sekolah Formal play group Jumlah SMP

$\begin{array}{rr}6 & 21 \\ 29 & 492 \\ 35 & 513\end{array}$

3

16

b. Sarana Kesehatan

Jenis Sarana Kesehatan

Jenis Sasaran Kesehatan

Paramedis

Dukun Bersalin Terlatih

Bidan

Jumlah (Unit/Orang)

Jumlah (unt/orang)

Perawat

3

1

2

4

6. Tingkat Pendidikan Masyarakat

Tingkat Pendidikan Laki-Laki Wanita Jml

$\begin{array}{llll}\text { Tamat SD/sederajat } & 275 & 414 & 689\end{array}$

Tamat SMP/Sederajat $\quad 240 \quad 292 \quad 539$

Tamat SMA/Sederajat $\quad 520 \quad 407 \quad 927$

$\begin{array}{lrrr}\text { Tamat D1/Sederajat } & 5 & 10 & 15\end{array}$

Tamat D3/Sederajat $\quad 29 \quad 37 \quad 66$

Tamat S-1/Sederajat $\quad 47 \quad 52 \quad 99$

Tamat S-2/Sederajat

Jumlah (Orang)

1.123

$1.214 \quad 2.337$

7. Sarana dan Prasarana

a. Kantor Desa/Kelurahan

Tidak ada data untuk ditampilkan

b. Kesehatan Kesehatan Jumlah (Unit)

- Jenis Prasarana Kesehatan

- Posyandu

1

- Rumah Bersalin

Jumlah

8

c. Pendidikan

Jenis Gedung Sewa (Gedung) Milik Sendiri jumlah

S.M.P/Sederajat

S.D/Sederajat

T.K

Tempat Bersalin

Tempat Pendidikan Agama 0

Jumlah

Sewa (Gedung)

dung)
0
2
1
1
0
4

d. Peribadahan

Jenis Tempat Ibadah

Masjid

$\begin{array}{cc}\text { Milik Sendiri } & \text { jumlah } \\ 1 & 1 \\ 0 & 2 \\ 0 & 1 \\ 0 & 1 \\ 3 & 3 \\ 4 & 8\end{array}$

Jumlah

5 


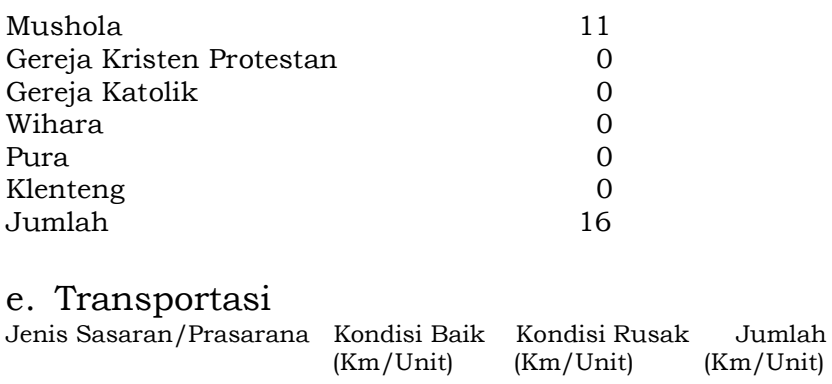

f. Air bersih

Sumur Pompa (unit) 0

Sumur Gali (Unit) 902

Hidran Umum (Unit) 0

Penampung Air Hujan (Unit) 0

Tangki Air Bersih (Unit) 0

Embung (Unit) 0

Mata Air (Unit) 0

Bangunan Pengolahan Air (Unit) 0

\section{g. Irigasi}

Panjang Saluran Primer $(\mathrm{m}) \quad 0$

Panjang Saluran Seunder (m) 0

Panjang Saluran Tersier (m) 0

Pintu Sadap (Unit) 1

Pintu Pembagi Air (Unit) 7

h. Sanitasi

Sumur Resapan Air Rumah Tangga

(Rumah)

752

MCK Umum (Unit)

1

Jumlah Keluarga (KK)

930

Saluran Drainase /

Saluran Pembuangan Air Limbah ada

Kondisi Saluran Drainase/Saluran 2

i. Olah Raga

Jenis Prasarana Olah Raga

Jumlah

Lapangan sepak bola (Unit/Gedung/Lokasi)

Lapangan bulu tangkis

1

Meja ping pong

1

Lapangan Tenis

Lapangan Voli
C. KEUANGAN

Pemasukan Anggaran

- APBD Kab/Kota (Rp)

20.355 .800

- Bantuan Pemkab/Kota (Rp)

5.000 .000

- Bantuan Pemerintah Propinsi (Rp)

55.000 .000

- Bantuan Pemerintah Pusat (Rp)

701.431 .000

- Pendapatan Asli Desa (Rp)

511.500 .000

- Swadaya Masyarakat Desa/

Kelurahan (Rp)

- Alokasi Dana Desa (Rp)

- Sumber Pendapatan dari Perusahaan yang ada di Desa (Rp)

268.756 .700

- Sumber Pendapatan Lain yang sah dan tidak mengikat

Jumlah Penerimaan Desa/

Kelurahan tahun ini (Rp)

1.567 .543 .500

D. KELEMBAGAAN

a. Lembaga Kemasyarakatan

Jenis Lembaga Jml Pengurus (orang) Jenis Kegiatan

Kelomp Gotong Royong $6 \quad 6 \quad 1$

Jumlah

6

6

1

b. Lembaga Adat

Pemangku Adat tidak ada

Kepengurusan Adat tidak ada

Rumah Adat

Barang Pusaka

Naskah-Naskah

Lainnya

tidak ada

tidak ada

tidak ada

tidak ada

E. KEAMANAN DAN KETERTIBAN

Jumlah Anggota Hansip (Orang) 14

Jumlah Anggota Satgas Linmas (Orang) 14

Jumlah Pos Kamling (Buah) 17

Konflik SARA (Kasus) 0

Perkelahian Massal (Kasus) 0

Penyerobotan Tanah/Perampokan (Kasus 0

Pembunuhan (Kasus) 0

Pencurian/Perampokan (Orang) 0

Mabuk Akibat Narkoba (Kasus) 0

Lokalisasi Prostitusi
5.500 .000

00


Badan Permusyawarat Desa diatur dalam Perda Kabupaten Kebumen Nomor 2 Tahun 2019 Tentang Badan Permusyawaratan Desa (BPD), Desa Sidomukti jumlah anggota BPD 7 (tujuh) orang yaitu Laki-Laki 4 (empat) dan Perempuannya 3 (tiga) dengan masa jabatan 2019 - 2025. Cara menentukan jumlah anggota BPD Desa Sidomukti sebagai berikut:

1. Penetapan jumlah anggota BPD sebagai mana dimaksud pada ayat (2) memperhatikan jumlah penduduk dan kemampuan keuangan Desa (pasal 5 ayat 3 (tiga)

2. Jumlah penduduk 2001 jiwa - 3.500 jiwa, skor sama dengan 2 (pasal 6, 1a.2)

3. Penetapan jumlah anggota BPD ditentukan berdasarkan penjumlahan skor jumlah penduduk dan kemampuan keuangan (APBDes), skor $2-3$, jumlah BPD sebanyak 5 orang (pasal 6, 2.a)

Panitia Pemilihan Kepala Desa Sidomukti, Kecamatan Adimulyo, Kabupaten Kebumen, Nomor : 07/PAN/2019 dalam berita acara rapat Penelitian Persyaratan Bakal Calon Kepala Desa Sidomukti pada hari Kamis, 9 Mei 2019 jam 19.00 WIB bertemppat di Balai Desa Sidomukti, dalam penelitian persyaratan Bakal Calon Kepala Desa yang dihadiri oleh anggota Panitia Pemilihan yaitu : Rusmanto SPd sebagai ketua, Rokhyadi sebagai sekretaris dan 17 (tujuh belas) sebagai anggota, 1 (satu) penjaga. Dalam rapat tersebut menyepakati hal-hal sebagai berikut :

1. Penelitian persyaratan Bakal Calon Kepala Desa Sodomukti telah dilaksanakan oleh Panitia Pemilihan sejak tanggal 7 Mei 2019 sampai dengan tanggal 9 Mei 2019 bertempat di Balai Desa Sidomukti.

2. Dari jumlah pelamar sebanyak 4 (empat) orang Bakal Calon Kepala Desa yang memenuhi persyaratan admistrasi sebanyak 4 (empat) orang, atas nama :

1) Nama SUPARMIN, usia 56 tahun, jenis kelamin laki-laki, tingkat pendidikan terakhir SLTP alamat Dusun Ketonggo Desa Sidomukti RT 04/02 Kec Adimulyo, Kab Kebumen (calon petahana/ incumbent)

2) Nama JONO RIYANTO, usia 60 tahun, jenis kelamin laki-laki, tingkat pendidikan terakhir STM alamat Dusun Sembir tengah Desa Sidomukti RT 03/06 Kec Adimulyo Kab Kebumen.

3) Nama HERU HUDIYONO, usia 58 tahun, jenis kelamin laki-laki, tingkat pendidikan terakhir SLTA alamat Dusun Penunggalan timur Desa Sidomukti RT 02/03 Kec Adimulyo Kab Kebumen.

4) Nama BAYU IKHTIAR, usia 52 tahun, jenis kelamin laki-laki, tingkat pendidikan terakhir SLTA alamat Desa Plarangan RT 01/01 Kec Karanganyar Kab Kebumen.

Dari 4 (empat ) Bakal Calon Kepala Desa Sidomukti SUPARMIN adalah calon petahana (incumbent) yang sudah menjabat 1 (satu) yaitu periode pertama 6 (enam) tahun telah berlalu (2014-2019), berikut adalah Visi dan Misi dari seluruh Bakal Calon Kepala Desa periode 2019 2025 sebagai berikut :

Calon Nomor urut 1 SUPARMIN VISI

Lanjutkan Pembangunan, Mboten NekoNeko dan Mengutamakan Musyawarah untuk Mufakat MISI

1. Meningkatkan Kesejahteraan Masyarakat

2. Meningkatkan Mutu Pelayanan Masyarakat dalam Segala Hal

3. Meningkatkan Sarana dan Prasarana Pertanian

4. Pembangunan yang Adil dan Merata 
5. Memberdayakan Semua Unsur Masyarakat dalam Pembangunan Desa Sidomukti

Calon Nomor urut 2 BAYU IKHTIAR VISI

Menciptakan Masyarakat Sejahtera Lahir dan Batin

MISI

10 Program PEMBANGUNAN DESA

SIDOMUKTI YAITU :

1. Ekonomi Desa

2. Kesejahteraan Sosial

3. Kesehatan

4. Riset dan Teknologi

5. Pendidikan Ketramilan-Ketrampilan

6. Kesadaran Hukum dan H.A.M

7. Pemberdayaan Sumber Daya Manusia (SDM)

8. Pengelolaan Sumber Daya Alam (SDA)

9. Budaya Seni Jawa dan Budi Pekerti

10. Budi Daya Pertanian, Peternakan, Perikanan Alokasi 20 \% Dana Desa (D.D)

\section{Calon Nomor urut 3 HERU HUDIYONO} VISI

Terwujudnya Desa Sidomukti yang Religius, Agraris, Aman, Sehat, Cerdas, Berdaya Saing, Berbudaya dan Berakhlak Mulia

MISI

1. Mewujudkan Keamanan dan Kebersihan di Lingkungan Desa Sidomukti

2. Meningkatkan Kesehatan, Kebersihan Desa serta mengusahakan Jaminan Kesejahteraan Masyarakat Melalui Program Pemerintah

3. Mewujudkan dan Meningkatkan serta Meneruskan Tata Kelola Pemerintahan Desa yang Baik

4. Meningkatkan Pelayanan yang Maksimal kepada Masyarakat Desa dan Daya Saing Desa

5. Meningkatkan Kesejahteraan Masyarakat Desa dengan Mewujudkan Badan Usaha Milik Desa (BUMDes) dan Program lain untuk Membuka
Lapangan Kerja Bagi Masyarakat Desa serta Meningkatkan Produksi Rumah Tangga Kecil

6. Meningkatkan Sarana dan Prasarana dari Segi Fisik, Ekonomi, Pendidikan, Kesehatan dan Kebudayaan di Desa Sidomukti

7. Miningkatkan Kehidupan yang Harmonis, Toleran, Saling Menghormati dalam Kehidupan Berbudaya dan beragama di Desa Sidomukti

8. Mengedepankan Kejujuran, Keadilan, Transparasi dalam Kehidupan Seharihari baik dalam Pemerintahan Maupun dengan Masyarakat Desa Sidomukti

Calon Nomor urut 4 JONO RIYANTO VISI

Terwujudnya Masyarakat Desa Sidomukti yang Tentram, Maju, Makmur dan

Berkeadilan

MISI

1. Melanjutkan Program-Program yang Telah dilaksanakan oleh Pemerintah Sidomukti Periode lalu, Sebagaimana Tercantum dalam Dokumen RPJMDes Desa Sidomukti

2. Memberdayakan Semua Potensi yang ada di Msyarakat, yang meliputi :

a. Memberdayakan Sumber Daya Manusia (S.D.M)

b. Memberdayakan Sumber Daya Alam

c. Pemberdayaan Ekonomi Kerakyatan

3. Menciptakan Kondisi Masyarakat Desa Sidomukti yang : Aman, Tertib, Guyub dan Rukun, dalam Kehidupan Bermasyarakat dengan Berpegang pada Prinsip-Prinsip yaitu :

a. Duduk sama Rendah berdiri sama Tinggi

b. Ringan sama dijinjing berat sama dipikul

4. Optimalisasi Penyelenggaraan Pemerintahan Desa Sidomukti, yang Meliputi : 
a. Penyelenggaraan Pemeintah yang Transparan dan akuntabel

b. Pelayanan Kepada Masyarakat yang Prima, yaitu : Cepat, Tepat, dan Benar

c. Pelayanan Pembangunan yang Berkesinambungan dan Mengedepankan Partisipasi dan Gotong Royong Masyarakat

Panitia Pilkades Desa Sidomukti membuat Slogan :

"Ayo Kita Sukseskan ...!!!

PEMILIHAN KEPALA DESA, DESA SIDOMUKTI, KECAMATAN ADIMULYO JANGAN LUPA TANGGAL 25 JUNI 2019 DATANG KE TPS

Mari Gunakan Hak Pilih Dengan Bijak PELAKSANAAN PEMILIHAN KEPALA DESA SIDOMUKTI

Pelaksanaan Pilkades Sidomukti terdiri dari 6 (enam) bilik pemungutan suara sesuai jumlah Dusun yaitu 6 (enam) yang dikepalai oleh seorang kepala dusun (Kadus) yaitu :

1. Dusun Kemasan jumlah hak pilih

Kadus 1 meliputi RT 01 - RT 04 RW 01

laki-laki $\quad=148$

wanita $\quad=164$

jumlah $=312$

2. Dusun Ketonggo Kebanaran (Toban) jumlah hak pilih

Kadus 2 meliputi RT 01 - RT 04 RW 02

Laki-laki $\quad=187$

wanita $\quad=227$

Jumlah = $=414$

3. Dusun Penunggalan timur dan Sembir timur jumlah hak pilih

Kadus 3 meliputi RT 01- 02 RW 03 dan RT 01-03 RW 05

\begin{tabular}{ll} 
Laki-laki & $=189$ \\
Wanita & $=199$ \\
\hline Jumlah & $=388$
\end{tabular}

4. Dusun Penunggalan tengah jumlah hak pilih

Kadus 4 meliuti RT 01 - Rt 03 RW 04

\begin{tabular}{ll} 
laki-laki & $=127$ \\
Wanita & $=145$ \\
\hline Jumlah & $=272$
\end{tabular}

5. Dusun Penunggalan barat dan Sembir barat jumlah hak pilih

Kadus 5 terdiri dari RT 03 - 04 RW 03 dan RT 01 - 03 RW 05

\begin{tabular}{ll} 
Laki-laki & $=232$ \\
Wanita & $=226$ \\
\hline Jumlah & $=456$
\end{tabular}

6. Dusun Sembir tengah jumlah hak pilih

Kadus 6 terdiri dari RT $01-03$ RW 06

\begin{tabular}{ll} 
Laki-laki & $=116$ \\
Wanita & $=135$ \\
\hline umlah & $=251$
\end{tabular}

Jumlah hak pilih Pilkades 25 Juni 2019

Desa Sidomukti yaitu

\begin{tabular}{ll} 
Laki-laki & 999 \\
Wanita & $=1.096$ \\
\hline Total Ahir & $=2.095$
\end{tabular}

Hasil Perhitungan Suara Untuk Calon Kepala Desa

Desa Sidomukti, 25 Juni 2019

Kecamatan Adimulyo

Kabupaten Kebumen

A. Suara Sah

\begin{tabular}{|l|l|c|c|c|c|c|c|c|}
\hline \multirow{2}{*}{ No } & \multirow{2}{*}{ Nama Calon } & \multicolumn{6}{|c|}{ Wilayah } & Suara \\
\cline { 3 - 9 } & & 1 & 2 & 3 & 4 & 5 & 6 & Sah \\
\hline 1. & Suparmin & 85 & 88 & 92 & 86 & 111 & 39 & 501 \\
\hline 2. & Bayu Ikhtiar & 8 & 2 & 1 & 2 & 6 & 0 & 19 \\
\hline 3. & $\begin{array}{l}\text { Heru } \\
\text { Hudiyono }\end{array}$ & 87 & 126 & 174 & 86 & 118 & 31 & 622 \\
\hline 4. & Jono Riyanto & 36 & 100 & 33 & 37 & 99 & 125 & 430 \\
\hline & $\begin{array}{l}\text { Jumlah Sah } \\
\text { Perwil }\end{array}$ & 216 & 316 & 300 & 211 & 334 & 205 & 1.572 \\
\hline
\end{tabular}

B. SUARA TIDAK SAH

\begin{tabular}{|l|l|l|l|}
\hline No. & Uraian & $\begin{array}{l}\text { Jumlah } \\
\text { Angka }\end{array}$ & Jumlah Huruf \\
\hline 1. & Suara Tidak Sah & 15 & Lima belas \\
\hline
\end{tabular}


Perolehan suara berdasarkan rangking (peringkat) yaitu :

\begin{tabular}{|l|l|c|c|}
\hline No & \multicolumn{1}{|c|}{ Nama Calon } & $\begin{array}{c}\text { Nomor } \\
\text { Urut }\end{array}$ & $\begin{array}{c}\text { Suara } \\
\text { sah }\end{array}$ \\
\hline 1 & Heru Hudiyono & 3 & 622 \\
\hline 2 & Suparmin & 1 & 501 \\
\hline 3 & Jono Riyanto & 4 & 430 \\
\hline 4 & Bayu Ikhtiar & 2 & 19 \\
\hline
\end{tabular}

Dari sebanyak 2.095 hak pilih yang menggunakan hak pilihnya 1.587 pemilih yaitu terdiri dari 1.572 surat suara sah dan 15 surat suara tidak sah, jadi yang tidak menggunakan surat suaranya sebanyak 508 pemilih (24\%).

Masa jabatan Kepala Desa Sidomukti periode 2014 - 2019 berakhir pada saat Kepala Desa Sidomukti periode 2019 2025 terpilih dilantik oleh Bupati Kebumen (Pergub Jawa Tengan No. 22 Tahun 2017 Tentang Pemilihan dan Pengangkatan Kepala Desa diubah dengan Pergub No. 31 Tahun 2017 Tentang Perubahan Atas Peraturan Bupati No. 22 Tahun 2017 Tentang Pemilihan dan Pengangkatan Kepala Desa dan diatur oleh Perda Kabupaten Kebumen No. 10 Tahun 2016 Tentang Pmilihan, Pengangatan Pemberhentian Kepala Desa) Petunjuk pilkades serenta tahun 2019 Kabupaten Kebumen.

Prestasi Desa Sidomukti

Periode 2014 - 2019

1. Lomba Desa BBGRM (Bulan Bakti Gotong Royong Masyarakat), Juara II tingkat Kabupaten Kebumen 2014

2. Rekor Muri Weku terpanjang di AlunAlun Kebumen 2015

3. Juara PKK Tentang Masak (buntil daun mangkokan, baso dari jantung, gulai sirsak muda), Juara I Tingkat Kabupaten Kebumen 2016

4. Juara PKK Tentang Administarasi PKK, juara I tngkat Kabupaten Kebumen 2017
5. Juara PKK Tentang Administrasi PKK, Juara II tingat Propinsi Jawa Tengah 2017

6. Juara Bunda PAUD Desa, Juara Harapan III tahun 2018

7. Juara Temu Kader PKK tingkat Propinsi Jawa Tengah tahun 2018

8. Lomba Desa BBGRM (Bulan Bakti Gotong Royong Masyarakat), Juara II tingkat Kabupaten Kebumen 2014

9. Lomba Cipta menu Menu B2SA (Beragam Bergisin Seimbang dan Aman), Juara I tingkat Kabupaten Kebumen dalam rangka hari pangan se-dunia yang ke 38 di Alun-Alun Kebumen 2018

10. Lomba Perpusdes (Perpustakaan Desa), juara II tingkat Kabupaten tahun 2018

11. Juara Lomba Makanan Weku terbesar mewakili Kecamatan Adimulyo pada tingkat Kabupaten kebumen yang mendapatkan rekor Muri

12. Sertifikasi Hak Milik Tanah sebanyak 2.011 bilang, Hak Pakai Tanah Milik Desa 203 bidang. Ada 24 tanah wakaf, baru ada 6 yang sudah tersertifikasi tanah wakaf tahun 2018

13. Senam Segar "SEDYO NGAWE RAHAYU" ada 4 kelompok di RW 1, RW 2, di Balai Desa Sidomukti, di RW 7 beranggotakan sekitar 400 lebih, untuk para penyandang Diabetes Melitus (DM), sejak dari tahun 2013 sampai tahun 2019

Dan lain-lain.

\section{PENUTUP}

Pelaksanaan Pilkades Desa Sidomukti tahap kedua yang dilaksanakan pada tanggal 25 Juni 2019 ini menarik untuk dicermati karena bentuk demokrasi pemilihan seorang kepala pemerintahan tingkat Desa secara langsung dan hal ini sudah berlangsung puluhan tahun, penulis yang lahir di tahun 1962-an 
waktu itu sudah ada Pilkades sejak duduk di bangku sekolah dasar (S.D) pun sudah ada Pilkades diwarnai dengan hal sama yaitu seperti klenik, jor-joran mengeluarkan biaya untuk menjamu dan membiayai segala urusan yang berkaitan dengan pencalonan Pilkades, dan masih adanya kabar selentingan adanya pihak yang main taruhan walaupun tidak seperti tahun 70-an dengan cara membantu dana kepada calon yang dimungkinkan akan menang, bahkan tersebar kabar selentingan (issue) adanya bagi-bagi uang (money politic), apabila hal itu benar adanya, maka benar-benar menciderai demokrasi, budaya seperti itu agaknya sulit diberantas dan sulit dibuktikan, karena ada yang memberi dan ada yang menerima (demand and suplay).

Penulis sengaja mengamati secara langsung dari Senin 24 Juni 2019 sampai pukul 02 dini hari Selasa, 25 Juni 2019 masyarakat mendatangi ke empat (4) rumah para kandidat Kepala Desa Sidomukti, sehingga para kandidat berlomba-lomba menyuguhkan jamuan yang beraneka macam seperti : makanan ringan, makan prasmanan, air mineral, teh, kopi bahkan masih mengirim makanan dan lauk pauk ke berbagai Dusun kepada para para botoh (orang kepercayaan yang menggalang masa) memang Desa Sidomukti tergolong Desa yang memiliki tanah Desa (hak ulayat/tanah bengkok) cukup besar sehingga menggiurkan untuk menduduki jabatan seorang Kepala Desa.

Pemda Kabupaten Kebumen sudah membuat regulasi yang sangat baik untuk menghasilkan aparatur pemerintah Desa yang jujur dapat dipercaya masyarakat dengan pilkades yang bersih dan bermartabat tanpa wuwuran. Namun kembali kepada moral (integritas) masyarakat Desa Simomukti sendiri.

Penandatanganan Pakta Integritas secara serentak, tanggal 12 Juni 2019,
Penyampaian undangan tanggal 10-18 Juni 2019, dan pelaksanaan Kampanye tanggal 19-21 Juni 2019 hari tenang 24 Juni 2019, pelaksanaan Pemungutan Suara tanggal 25 Juni 2019 yang serentak digelar di 52 Desa.

Pilkades Sidomukti periode 2019 2025 terpilh dilantik oleh Bupati Kebumen (Pergub Jawa Tengan No. 22 Tahun 2017 Tentang Pemilihan dan Pengangkatan Kepala Desa diubah dengan Pergub No. 31 Tahun 2017 Tentang Perubahan Atas Peraturan Bupati No. 22 Tahun 2017 Tentang Pemilihan dan Pengangkatan Kepala Desa dan Perda Kabupaten Kebumen No. 2 Tahun 2016). Berdasarkan Perda Kabupaten Kebumen No. 10 Tahun 2016 Tentang Pemilihan, Pengangkatan, Pemberhentian Kepala Desa.

Slogan Panitia Pemilihan Desa Sidomukti Tanggal 25 Juni 2019 dengan slogan sebagai berikut :

Mari kita wuhudkan sebaga "PILKADES SERENTAK DI KABUPATEN KEBUMEN TAHUN 2019 YANG BERSIH DAN BERMARTABAT TANPA WUWURAN UNTUK MENCIPTAKAN APARATUR PEMERINTAH DESA YANG AMANAH, JUJUR, DAN DIPERCAYA MASYARAKAT"

Menurut Icuk Rangga Bawono dan Erwin Setyadi (2019) Peran desa dalam perekonomian dan pembangunan meliputi :

1. Desa sebagai Hinterland

Suatu desa bisa menjadi hinterland di mana Desa biasanya lebih banyak memproduksi dibandingkan mengkonsumsi, seperti penghasil bahan pangan, kopi, teh, kerajinan tangan, dan hasil pertanian, prikanan, dan perkebunan. Secara ekonomi, desa juga sebagai lumbung bahan mentah bagi industri yang ada di kota.

2. Desa sebagai Sumber Tenaga

Rata-rata para pekerja di kota merupakan mereka yang berasal dari suatu Desa, banyak masyarakat Desa yang mau 
bepergian atau merantau sampai jauh untuk memperoleh pekerjaan. Perusahaan yang membuka cabang di daerah yang jauh dan terpencil pun mudah mencari tenaga kerja yang mau bekerja

3. Desa sebagai Bentuk Pemerintahan

Desa merupakan bentuk pemerintahan terkecil di Negara Kesatuan Republik Indonesia terdapat 74. 957 Desa. Adanya pemerintahan terkecil membantu banyak petinggi untuk dikelola dan dihasilan oleh pihak pemerintahan yang lebih kecil dan lebih dekat dengan warga.

4. Desa merupakan Mitra Pembangunan

Desa merupakan awal terbentuknya kota, maju atau mundurnya suatu kota bermula dari titik Desa, oleh karena itu, Desa dapat disebut sebagai mitra bagi pembangunan kota. Fungsi Desa sebagai mitra (patner) pada saat ini dan yang akan datang bagi pembangunan kota adalah sebagai tenaga penggerak pembangunan kota. Hal tersebut dapat tercapai jika beberapa kriteria dapat terpengaruhi. Kriteria tersebut adalah sebagai berikut :

a. Pemimpin Desa dapat mengarahkan ataupun mendorong warga Desa agar berpikir maju, serta meningkatkan kesejahteraan hidup

b. Aparatur Desa dapat menjaga ketertiban administrasi Desa

c. Warga Desa mampu menyesuaikan diri terhadap pembangunan Desa

Menurut Bintarto (1984), watga Desa dapat menjadi patner pembangunan kota jika kehidupan modern telah dikenal, serta dimmiliki masyarakat pedesaan. Ciri-ciri kesiapan dari warga Desa, yaitu sebagai berikut :

a. Dapat berfikir maju tanpa mengabaikan pengalaman masa lampau

b. Memiliki perencanaan yang masuk akal atau rasional

c. Memiliki kemauan menerima pegalaman baru maupun terbuka terhadap pembaruan d. Mau menerima kritik dari pihak lain yang berdampak positif

e. Memiliki penghargaan terhadap orang lain

f. Mampu menghadapi dan mengatasi masalah yang ada

g. Menyelesaikan masalah dengan tindakan yang teratur, serta teliti

h. Berpegang pada segala sesuatu yang mampu diperhitungkan

i. Memiliki kepercayaan terhadap ilmu pengetahuan serta teknologi

Kementrian Dalam Negara Republik Indonesia No. 137 Tahun 2017 Tentang Kode dan Data Wilayah Administrasi Pemerintahan, di mana terdapat 416 Kabupaten, 98 Kota, 7.094 Kecamatan 8.490 Kelurahan dan $\mathbf{7 4 . 9 5 7}$ Desa di Indonesia.

\section{DAFTAR PUSTAKA}

Literatur

(software) Playstore Samsung, Buku Pintar Dana Desa Terlengkap, 2019

Bawono Icuk Rangga, Optimalisasi Potensi Desa Di Indonesia, Jakarta, Gramedia, 2019

Perundang-Undangan

Indonesia, Undang-undang Nomor 6 Tahun 2014

------------, Peraturan Pemerintah R.I Nomor. 43 Tahun 2014 Tentang Peraturan Pelaksanaan UndangUndang Nomor 6 Tahun 2014

-----------, Peraturan Pemerintah R.I Nomor 60 Tahun 2014 Tentang Dana Desa Yang Bersumber Dari Anggaran Pendapatan Dan Belanja Negara 
Sumber Lain

http//dprd-kebumen.go.id diunduh, Kamis, 20 Juni 2019 jam 20.33

www.kebumenekspres.com diunduh, Kamis, 20 Juni 2019 jam 21.26 